Marcin MENKES

Collegium of Management and Finance, Warsaw School of Economics

\title{
Chosen Aspects of the Implementation of International Humanitarian Law in Poland
}

\section{Introduction}

The issue of implementation of the international humanitarian law in Poland belongs to a broader problem of implementation of international law on the grounds of national civil-law legal systems; due to particular functions and features of IHL, the question of its implementation is even more complex.

I begin my analysis with a brief characteristic of the polish legal system in terms of implementation of international law, its position within the hierarchy of legal acts and applicability of international law provisions in Poland (part II); subsequently I scrutinise fundamental features of implementation of IHL (part III); in the end I analyse certain accomplishments and challenges yet to be undertaken by Poland in pursue of providing international standards of protection in case of an armed conflict (part IV).

\section{Polish Legal System}

Position of international law within Polish legal system

Article 87 of the Constitution of the Republic of Poland of $1997^{1}$, the superior act of the polish legal system, provides an exclusive list of sources of the universally binding law, which are respectively: the Constitution itself, statutes, ratified international treaties, ordinances and enactments of the local law ${ }^{2}$. The system is based upon a hierarchical structure,

1 Journal of Law No. 78, Item 483.

2 Article 87: “(1) the sources of universally binding law of the Republic of Poland shall be: the Constitution, statutes, ratified international agreements, and regulations. (2) Enactments of local law issued by the operation of organs shall be a source of universally binding law of the Republic of Poland in the territory of the organ issuing such enactments", http://www.sejm.gov.pl/prawo/konst/angielski/kon1.htm. 
including principles of compatibility of hierarchically lower acts with supreme acts and lex superior derogat legi inferiori.

International treaties ratified accordingly to the procedure under article 89(1), described further on, are inferior to the Constitution, but, in case of collision of norms, have precedence over statutes and other legal acts.

In terms of national application of international law, in order to be legally binding international agreements shall be promulgated in accordance with the procedures required for statutes, including an appropriate vacatio legis $^{3}$.

On the basis of article 9 of the Constitution, Poland respects the binding international law, accordingly to the general principle of law of fulfilling international obligations in good faith. The article provides for a "sympathetic approach" towards international law, including presumption of automatic, though indirect, incorporation of international norms into the national legal system ${ }^{4}$. Also other sources of international law not included in the exclusive enumeration of the Article 87, such as general principles of law or international customary law, fall under the scope of the article 9. Despite rejection of an initiative to include acknowledged principles of the international law among sources of the universally binding law ${ }^{5}$, Poland is not relieved from their obedience. This may be a source of problems in case of lack of implementation, in terms of national application of international law. Similarly the constitutionally essential distinction between treaties ratified on the grounds of procedure of Article 89(1) and other treaties, is irrelevant on the grounds of international law, as confirmed by the Article 27 of the Vienna Convention on the Law of Treaties 1969.

\section{Procedure of ratification of international treaties}

The act of ratification of international treaties belongs to competences of the President ${ }^{6}$. Poland may express consent to bind itself with a treaty

3 Article 88 (2) of the Constitution: "International agreements ratified with prior consent granted by statute shall be promulgated in accordance with the procedures required for statutes. The principles of promulgation of other international agreements shall be specified by statute".

4 L. Gardocki, Polskie Prawo Konstytucyjne, Liber, Warszawa 2002, p. 147.

5 Ibidem.

6 Article 89 (2) of the Constitution: "The President of the Council of Ministers (the Prime Minister) shall inform the Sejm of any intention to submit, for ratification by the President of the Republic, any international agreements whose ratification does not require consent granted by statute". 
also by an approval ${ }^{7}$, signature, accession, exchange of notes or other way provided by the international law $^{8}$. International agreement specified in the art. $89(1)^{9}$ and $90^{10}$ of the Constitution as well as other agreements, which include a duty of ratification or allow such ratification, if it is justified by the circumstances, shall be ratified ${ }^{11}$. Other agreements are approved by the Council of Ministers. Agreements are ratified or approved upon tender of a formal motion by a competent authority ${ }^{12}$.

To the extent and in accordance with principles specified by the Constitution and statutes, the Council of Ministers concludes international agreements requiring a ratification ${ }^{13}$ and approves and denounces other international agreements. Ratification of agreements listed in the art. 89 (1) of the Constitution requires an anticipatory Parliament's approval in a form of statute. The Statute on International Treaties regulates in details the procedure of the ratification of international agreements.

Prior to ratification the President may ask the Constitutional Tribunal for its opinion upon the conformity of the agreement with the legal order ${ }^{14}$.

A ratified international agreements, once promulgated, constitute a part of the national legal system and are subject to direct application, unless their application depends upon enactment of a statute ${ }^{15}$; the act of ratification introducing the act into the legal system has thus a transformative effect ${ }^{16}$.

There are no impediments to conclusion of treaties without ratification; such treaties, however, do not constitute a source of the universally binding $\operatorname{law}^{17}$.

7 Art. 12 (1) of the Statute on International Treaties of 2000 (SIT), Journal of Law No. 39, Item 443 amended Journal of Law No. 216, Item 1824 of 2002.

8 Art. 13 (1) STI.

9 Article 89 enumerates agreements concerning 1) peace, alliances, political or military treaties; 2) freedoms, rights or obligations of citizens, as specified in the Constitution; 3) the Republic of Poland's membership in an international organization; 4) considerable financial responsibilities imposed on the State; and 5) matters regulated by statute or those in respect of which the Constitution requires the form of a statute.

10 Agreements which delegate to an international organization or international institution the competence of organs of State authority in relation to certain matters.

11 Art. 12 (2) STI.

12 Art. 14 STI.

13 Article 146 (4)(10) of the Constitution.

14 Article 122 (3) of the Constitution.

15 Article 91 (1) of the Constitution.

16 Supra przypis 4, p. 149.

17 Ibidem. 
Treaties ratified without prior consent of the Parliament, contrary to those adopted under the Article 91(2) of the Constitution, are inferior to statutes in the hierarchy of legal acts ${ }^{18}$.

\section{Implementation of international humanitarian law}

\section{Particular character of IHL Implementation}

The main function of humanitarian law is to restrain unnecessary suffering and deaths resulting from the use of means and methods of conduct of warfare. This in turn results from the acknowledgment that those are the States, not men, who are enemies in an armed conflict. This perception, however, differs on a battlefield, where the relevant norms are to be applied. Belligerents can hardly be expected to act rightly and nobly while faced with starvation, pain, and war atrocities, deprived of what their previous life consisted of, unless they were trained to do so ${ }^{19}$. Implementation of humanitarian is rather a question of prevention of breaches and stigmatization of the inflicted harm in the peacetime, than of its enforcement in an armed conflict.

One shall not forget that due to particular time of application of IHL non-legal factors, such as religious and ethical believes of belligerents, attitude of public opinion or military routine, may be of greater importance than the letter of the law.

Also a contribution of international organizations and NGOs towards proliferation and implementation control of human rights protection standards shall not be underestimated; the two play significant role of as a politically non-involved objective party.

Due to limited length of the paper, I shall analyse merely actions undertaken since 1989 by Polish authorities.

18 Further: M. Masternak-Kubiak, Umowa Międzynarodowa w Prawie Konstytucyjnym, PWN, Warszawa 1997.

19 R. Jasica, Discussion on national application of international customary law in armed conflicts, in: National Implementation of International Humanitarian Law, eds. M. Bothe, T. Kurzidem, P. Macalister-Smith, Martinus Nijhoff, Dordrecht 1990, p. $52-53$. 


\section{Measures taken in the peacetime}

Implementation of any norm of law consists of two stages. Firstly occurs a legal situation falling under a hypothesis of a legal norm; then through a subsumption process the law is applied. While analyzing implementation achievements, it is therefore necessary, to perceive both legal and factual actions undertaken.

The roots of the implementation process reach international law plane. Once a state indentified an agreement by which it is bound, it shall consider if a transformation of the law is necessary and whether further legislation of national application is requisite. Translation of international law acts to national language may be required by the law, as it is in Poland.

Particularity of IHL begins at the promulgation stage. Unlike the grounds of civil or administrative law, knowledge of the humanitarian law by the subjects concerned cannot be presumed. Duties of states include: a proper translation of the law comprehensible to target groups, dissemination, both among members of armed forces and civilian population; and training of qualified personnel.

Numerous rules of IHL require also practical measures of implementation, just to mention proper marking of medical units or cultural objects.

Due to complexity of factual situations and great number of subjects concerned, measures are spread along national legal system, affecting all its branches and numerous authorities in the process of implementation. Poland is no exception to the rule.

\section{Implementation of IHL in Poland}

Social, economic and political changes begun in Poland in the year 1989 are of particular importance to national military doctrine in terms of humanitarian laws protection. During the two following decades Poland emerged from the communist block, joined the Council of Europe, the NATO and the European Union; modifications of the law were necessary at each step. In 1997 the new constitution was adopted. All the codes and statutes are being revised, still most of them dating back from previous period. That's what has been achieved so far. 


\section{Legislation}

\section{Constitution}

Enacted on April 2, 1997 the Constitution for the first time contains political, social and economical rights and freedoms, deemed natural and inherent for the human being in the western civilization.

Chapter II: The Freedoms, Rights and Obligations of Persons and Citizens:

- Anyone deprived of liberty shall be treated in a humane manner, Article 41 (4);

- Only a person who has committed an act prohibited by a statute in force at the moment of commission thereof, and which is subject to a penalty, shall be held criminally responsible. This principle shall not prevent punishment of any act which, at the moment of its commission, constituted an offence within the meaning of international law, Article 42 (1);

- Everyone shall comply with his responsibilities and public duties [...], as specified by statute, Article 84;

- Article 85:

1) It shall be the duty of every Polish citizen to defend the Homeland,

2) The nature of military service shall be specified by statute,

3) Any citizen whose religious convictions or moral principles do not allow him to perform military service may be obliged to perform substitute service in accordance with principles specified by statute.

\section{Ratified International Treaties ${ }^{20}$}

Victims of Armed Conflicts:

- Geneva Conventions I-IV, August 12, 1949; 26.11.1954; reservations $^{21}$;

- AP I, AP II, Geneva, June 8, 1977; 23.10.1991; reservations;

- AP III, Geneva 2005; 20.06.2006;

- Declaration provided for under Art. 90 AP I; 02.10.1992;

- Convention on the Rights of the Child, New York, November 20, 1989; 07.06.1991;

20 Updated regularly ICRC register of international treaties adherence, http://www.adh-geneva.ch/RULAC/international_treaties.php?id_state=172.

21 All the reservations have been repealed on the basis of Statute of 2004 (Journal of Law No. 29, Item 254). 
- Optional Protocol to the CRC 1989 on the Involvement of the Children in Armed Conflict, New York, May 25, 2000; 07.04.2005.

International Criminal Court:

- Rome Statute of the ICC, July 17, 1998; 12.11.2001;

Protection of Cultural Property in the Event of Armed Conflict:

- Convention for the Protection of Cultural Property in the Event of Armed Conflict, The Hague, May 14, 1954; 06.08.1956;

- $1^{\text {st }}$ Protocol to the 1954 HC, The Hague, May 14, 1954; 06.08.1956.

Not ratified:

- $2^{\text {nd }}$ Protocol to the 1954 HC, The Hague, March 26, 1999.

Environment:

- Convention on the Prohibition of Military or Any Other Hostile Use of Environmental Modification Techniques, New York, December 10, 1976; 08.06.1978.

Weapons:

- Protocol for the Prohibition of the Use of Asphyxiating, Poisonous or Other Gases, and Warfare, Geneva, June 17, 1925; 04.02.1929;

- Convention on the Prohibition of the Development, Production and Stockpiling of Bacteriological (Biological) and Toxin Weapons and on their Destruction. Opened for Signature at London, Moscow and Washington, April 10, 1972; 25.01.1973;

- Convention on the Prohibition of the Development, Production, Stockpiling and Use of Chemical Weapons and on their Destruction, Paris, January 13, 1993; 23.08.1995;

- Convention on Prohibitions or Restrictions on the Use of Certain Conventional Weapons which may be deemed to be Excessively Injurious or to have Indiscriminate Effects, Geneva, October 10, 1980; 02.06.1983;

- Protocol on non-detectable fragments (CCW I Protocol); 02.06.1983;

- Protocol on prohibitions or restrictions on the use of mines, booby-traps and other devices (CCW II Protocol); 02.06.1983;

- Protocol on prohibitions or restrictions on the use of incendiary weapons (CCW III Protocol); 02.06.1983;

- Protocol on Blinding Laser Weapons (CCW IV Protocol); 23.09.2004; 15.09.2006;

- Protocol on Prohibitions or Restrictions on the Use of Mines, Booby-Traps and Other Devices as amended on May 3, 1996 (Amendment to the CCW II Protocol); 14.10.2003;

- Convention on Prohibitions or Restrictions on the Use of Certain Conventional Weapons Which May be Deemed to be Excessively Injurious 
or to Have Indiscriminate Effects, Amendment article 1 (CCW Amendment); 15.09.2006;

Not ratified:

- Convention on Cluster Munitions, Dublin, May 20, 2008;

- Protocol on Explosive Remnants of War to the Convention on Prohibitions or Restrictions on the Use of Certain Conventional Weapons which may be deemed to be Excessively Injurious or to have Indiscriminate Effects (Protocols V). Geneva, November 28, 2003;

- Convention on the Prohibition of the Use, Stockpiling, Production and Transfer of Anti-Personnel Mines and on their Destruction, Oslo, 18 September 1997; signed by Poland on December 4, 1997.

\section{War crimes responsibility}

- Penal Code 22 of June 6, 1997 replaced the one of 1969. New statute organises provisions, which were either absent or used to have other meaning.

Chapter XVI contains war crimes, crimes against humanity, genocide crime, which in majority are new to Polish legal system, incorporation of which was an act of fulfilment of international obligations. The Code contains provisions relating to aggressive war, extermination, violence and unlawful threats, means of massive annihilation, unlawful means and methods of warfare, assassination upon persons, attacks on protected cultural objects, unlawful use of protective signs and other breaches of international law. Chapter XVI enumerating crimes against the Republic of Poland, recognizes forbidden under IHL espionage; Chapter XVII relating to crimes against national security discusses issues of terrorist attacks and mercenaries.

- Act of Government on Representative of the Government for International Organs of Control of Implementation of Human Rights ${ }^{23}$;

- Statute on National Memorial Institute - Commission for Chasing the Crimes Against Polish Nation of December 18, $1998^{24}$.

\section{Armed Forces Status}

- Act of Minsters of Defence and Internal Affairs on identity cards and tags in armed forces ${ }^{25}$; the ordinance introduces cards and tags for mem-

22 Journal of Law No. 88, Item 553 with further amendments.

23 Journal of Law No. 34, Item 188 of 1998.

24 Journal of Law No. 155, Item 1016 of 1998 and No. 38, Item 360 of 1999.

25 M. P. No. 65, Item 585 of 1994. 
bers of military armed forces, members of medical personnel, personnel of Polish Red Cross and other voluntary organisations auxiliary to military medical personnel, religious personnel.

\section{Civil Defence and Cultural Property}

- Statute on military tombs and cemeteries ${ }^{26}$ gives a definition of military tomb much broader than the one in the following Statute; the Act places such tombs and cemeteries under special protection of the State;

- Statute on cemeteries and death burial ${ }^{27}$;

- Statute on Protection of Cultural Property ${ }^{28}$ formulates the definition of Protected Cultural Property, introduces a special record of such objects and places them under protection of the State;

- Act of the Minister of Culture on means and methods of protection of cultural property in the event of an armed conflict and crisis situations ${ }^{29}$ includes plans of protection and realisation thereof and emblems of protective signs of the Hague Convention;

- Statute on common obligation of defence of the Republic of Poland ${ }^{30}$ sets goals and structure of organisation of Civil Defence; the Act sets the scope of obligation of defence put upon the citizens enumerating duties during peace time, in case of mobilization and state of war; it expressly states that property specially protected under the Hague Convention for the Protection of Cultural Property in the Event of Armed Conflict of 1954 cannot serve as contribution towards defence expenses, whereas objects under general protection are admissible only having obtained consent of proper authority;

- Act of Government on contributions for civil defence ${ }^{31}$;

- Act of Government on scope of duties put upon heads of Civil Defence units and on co-ordination of their activities ${ }^{32}$;

- Act of government on Civil Defence ${ }^{33}$;

26 Journal of Law, No. 39, Item 311 of 1992; No. 11, Item 62 1959; No. 34, Item 198 1990; No. 106, Item 6681998.

27 Journal of Law, No. 23, Item 295 of 2000.

28 Journal of Law, No. 98, Item 1150 of 1999.

29 Journal of Law, No. 212, Item 2153.

30 Journal of Law, No. 4, Item 16 of 1992 with further amendments.

31 Journal of Law, No. 85, Item 397 of 1993.

32 Journal of Law, No. 91, Item 420 of 1993.

33 Journal of Law, No. 93, Item 429 of 1993. 
- Act of government on common self-defence ${ }^{34}$ obliges citizens to participate in self-defence courses including protection of life and health, protection of households and administering first-aid; training shall be organised in co-operation of local self-government and civil-defence units;

- Act of the Head of Civil Defence on distinctive signs and uniforms of Civil Defence ${ }^{35}$;

- Act of Minister of Culture and Art on protection of Cultural Property in case of danger to national security and armed conflict ${ }^{36}$;

- Statute on cantonment of Armed Forces of the Republic of Poland ${ }^{37}$ in relation to protected objects under Hague Convention for the Protection of Cultural Property in the Event of Armed Conflict of 1954 and $1^{\text {st }}$ Additional Protocol to Geneva Convention of 1954 lists localisations, which cannot be seized by armed forces for its cantonment at any time;

- Act of the Government introducing Polish Advisory Committee for Protection of Cultural Property in case of an armed conflict ${ }^{38}$ in relation to $2^{\text {nd }}$ resolution to the Hague Convention of 1954; the body is supervises process of implementation of the Convention.

\section{Polish Red Cross}

- Statute on Polish Red Cross ${ }^{39}$ constituting the PRC. Among its duties the act enumerates training and care for sanitary issues, providing assistance for persons protected under international treaties, especially under the Geneva Law and governing National Bureau of Information as stipulated in international treaties relating to POWs and protection of civil population in the event of an armed conflict.

\section{Other legislation}

- Act of the President of the Republic of Poland on prohibition of use of white and yellow phosphor in production of incendiary Items ${ }^{40}$.

34 Journal of Law, No. 91, Item 421.

35 M. P. No. 6, Item 100; No. 39, Item 470 of 1995.

36 DzUrzed. MKiSz, No. 4, Item 14 of 1995.

37 Journal of Law, No. 86, Item 433 of 1995 with further amendments.

38 Dz. Rozk. MON, Item 182 of 1996.

39 Journal of Law, No. 41, Item 276 of 1964.

40 Journal of Law, No. 43, Item 380 of 1927. 
- Act of the Government on prohibition of export of antipersonnel mines from the Polish duty zone ${ }^{41}$ for other than military training or operations purposes;

- Act of the Prime Minister introducing Group for International Humanitarian $\mathrm{Law}^{42}$ responsible for dissemination, in order to introduce to Polish legal system, provisions of IHL; among other measures its goals are to be achieved through review and analysis of IHL treaties and formulating opinions upon them; giving opinions and suggestions to the Prime Minister on steps, which shall be undertaken while fulfilling international obligations; suggestions on needed legislation; co-operation with other institutions specialised in the topic - particularly Polish Red Cross; analysis of undertaken measures; drafting programmes of IHL courses; giving opinions on Polish approach at international conferences; co-operation with foreign organisations specialized in IHL.

\section{Practical Approach}

\section{Dissemination in Armed Forces}

- As previously stated, none can expect soldiers participating in hostilities to act according to IHL provisions, unless they had been previously specially prepared during their regular training to apply those rules, hence the importance of this factor doesn't need any further explanation. First works on introducing humanitarian law as a subject at military schools were undertaken in 60's; in 80's teaching of the subject has been regulated by law (Act of Minister of Defence No. 64/MON of November 1982), however, the topic was still being treated rather as a theoretical issue; change of attitude with more practical approach dates back to the subsequent decade. Nowadays, the Ministry of Defence co-operates closely with Polish Red Cross in organisation of courses and disseminating schooling materials. Since 1991 Armed Forces co-operate also with the Helsinki Human Rights Foundation, who train professional soldiers in teaching the subject, with main focus upon $\mathrm{Hu}-$ man Rights. Since 1995 exists specific indication by Minster of De-

41 Journal of Law, No. 52, Item 321 of 1998.
42 M. P. No. 23, Item 402 of 2004. 
fence of topic concerning IHL which shall be covered in the course of academic education. Currently a course on laws of armed conflicts is obligatory at all levels of military schools and academies; all regular soldiers participate in a course of IHL; special courses for commanding officers of battalions and brigades are organised in co-operation with ICRC; special courses for officers co-ordinating protection of cultural property at all levels; they are constantly being provided with numerous publications. Since 1997 a co-operation for developing system of education between the Ministry and the Budapest delegation of ICRC can be observed. Apart from national training, thanks to ICRC assistance, number of Polish officers is sent annually to San Remo for a special course organised by the International Institute of Humanitarian Law. Numerous other initiatives are impossible to list within limited the scope of the research;

- As a part of co-operation of allied Armed Forces, Polish military presence abroad is constantly growing in last decade. Coming across problems unknown to soldiers serving back in the Country, was pretty often source of great difficulties and confusion while fulfilling their daily duties, i.e. especially generally criticised, due to grave misunderstanding, presence of Polish archaeologist in the Military Camp Alpha Site in Babylon gave an evidence of how important is proper preparation for such missions. For that aim the Ministry of Foreign Affairs undertook various extra measures including:

- Special courses on IHL obligatory for all participants of foreign mission before departure;

- Extra courses for headquarters of the mission providing more information proportionate to their broader responsibility and scope of tasks;

- Provision of all members of the personnel going to a foreign mission with a special kit containing leaflets covering basic provisions of IHL (including brief description of nature of Geneva Conventions, basic rules of conduct of warfare, rules of responsibility for the conduct, list of forbidden means and methods of warfare and some basic provisions concerning civil population, injured, sick and wounded, killed and enemies property as well as basis protective signs). The kit contains also small vademecum issued by the Ministry of Defence in co-operation with the Ministry of Foreign Affairs containing all the data useful in the region of activity. Books written for each country separately cover such diverse elements as history and culture 
of the State, local habits and traditions, basic geopolitical knowledge as well as information on threats by local fauna and flora. Before every shift of contingent the book is being revised and updated;

- Various competitions held throughout the country, which main purpose is dissemination of knowledge both on general aspects of IHL and more specific issues, like cultural property protection; competitions are organised by the Armed Forces for members of military personnel as well as by civil organisations - i.e. Ministry of Education (http://www.men.gov.pl/menis_pl/glowna/index.htm) - for civilian population.

\section{International cooperation}

- On May 20, 2004 the Prime Minister constituted the Polish Commission for International Humanitarian Law Affairs ${ }^{43}$, a consultative and advisory body to the Prime Minister. Composed of composed of the chairman, an undersecretary in the Ministry of Foreign Affairs, the deputy-chairman, a representative of the head of the Prime Minister's Office, representatives of the ministers in charge of home affairs, public administration, foreign affairs, public finances, culture and protection of national heritage, science, public health, higher education, national defence and justice, a secretary appointed by the chairman and other persons invited by the Commission's chairman it is meant to promote standards of international humanitarian law and introduce them into the Polish legal system. Its competences encompass presenting analysis of international agreements on international humanitarian law and appropriate implementation legislative initiatives; presenting views upon legislative and educational activities in the field of IHL, analysing legislation prepared, government programmes and other documents; preparing projects for educational programmes in the field of IHL. The Commission also competent to maintain ties with other committees in Poland and abroad concerned with international humanitarian law, and to formulate Polish position at international conferences (based on proposals of the minister in charge $)^{44}$.

43 M. P. No. 23, Item 402 of 2004.

44 ICRC, National implementation of international humanitarian law. Biannual update on national legislation and case law. January-June 2004, p. 702-703, http://icrc.org/Web/eng/siteeng0.nsf/htmlall/66DF66/\$File/irrc_855_Nat_impl.pdf. 
- On the September 9, 2006 in Warsaw was signed an agreement, on basis of which Poland eventually joined member States of the CIMIC programme, for enhancing co-operation between civil and military personnel, especially important in terms of preventive measures of protection of cultural property including preparation of database of such objects and their description. In Land Forces, a structure of cells responsible for civilian-military co-operation down to brigade level has already been created;

- As a random example of Polish initiatives for enhancing such a co-operation let serve the International Conference on $50^{\text {th }}$ Anniversary of Signing The Hague Treaty Conference of 1954 for the Protection of Cultural Property in the Event of Armed Conflict held in Warsaw under auspices of the UNESCO Director General or the Regional Seminar on the National Implementation of the $\mathrm{HC}$ and its Protocols organised by the Ministry of Culture in association with the ICRC and The Polish Red Cross.

\section{Dissemination among civil population}

- Act of the Minister of Education and Sports on teaching of civil defence $^{45}$ makes the subject obligatory for pupils of all types of schools above the secondary; the classes shall be held one hour per week for the period of two years and include first-aid administrating, planning and organisation of operations;

- IHL as a branch of international law is being taught at all Law Faculties of Poland; even though there hasn't been yet created an obligatory programme-minimum for international law classes, it can be noticed that numerous faculties organise for students extra lectures on IHL apart from the main course, which undoubtedly broadens the given information;

- Polish Red Cross actively participates in numerous activities, goal of which is promotion if IHL; for that purpose a special Commission for Dissemination of International Humanitarian Law embodying numerous academics, representatives of various ministries (i.e. Defence, or of Foreign Affairs), representatives of Police and Fire Brigades Departments, workers and voluntaries of the PRC was founded in 1979;

45 Journal of Law No. 113, Item 987 of 2002. 
among other initiatives it is worth to mention the Summer IHL School in Radziejowice, organised annually by the ICRC in co-operation with the PRC ${ }^{46}$;

- As mentioned above, the Act of government on common self-defence obliges citizens to participate in self-defence courses organised by Civil Defence. Though obligatory trainings are not common in Poland, some activity at the field has been noticed. For instance courses organised by the Headquarters of National Fire Brigades Agency on Civil Defence (www.straz.gov.pl/?p=/szkolenie/szkolociol/), teaching materials provided by the Police Department (http://www.kgp.gov.pl/index.php?dzial=42), and some basic information covering the issue on the web site of Polish Civil Defence (http://www.obronacywilna.pl/szkoleni.html);

- In 1997 by initiative of Minister of Defence and Internal Affairs and Administration a Population and Cultural Property Protection Training Centre was founded in Cracow, schooling members of armed forces, members of cultural property protection services, heads of institutions of culture, Fire Brigades and Civil Defence, monuments conservators and others, both Polish and foreigners.

\section{Protection of cultural property}

- Decision of the Minister of Defence on respecting rules of protection of cultural property during actions of Armed Forces of the Republic of Po$\operatorname{land}^{47}$ with additional instruction on rules of protection and forms for monitoring of such protection;

- In 1998 a cell specializing in protection of cultural property in case of an armed conflict within the Ministry of Defence was founded;

- CD 'Base of the protected cultural objects in the Republic of Poland' issued on demand of the Ministry of Defence containing all protected cultural objects, with their brief description, pictures and precise localisation; the record has been sent to headquarters of numerous armed forces and was commonly judged as the best worldwide database yet created;

46 K. Derlicka, Vingt ans de DIH en Pologne, Magazine du Mouvement International de la Croix-Rouge et du Croissant-Rouge, http://www.redcross.int/FR/mag/magazine2003_2/index.html.

47 Dz.Urzed. MON No. 15, Item 135 of 2005. 
- During the period of 2004-2005 a special Polish Advisory Committee used to support the Governments in its actions towards proper implementation of IHL provisions; since establishment of the new cabinet a year ago it is yet undecided if the Committee will carry on with its duties;

- As an example of IHL provisions in action can well serve over 24 projects realised by the Specialist for Archaeology and Protection of Cultural Property accredited by Polish Armed Forces in Iraq in the period between November 2003 through February 2005 for estimated cost of over 670 thousands USD and with numerous initiatives still in progress.

\section{Polish Red Cross}

- Among major tasks of National Associations of Red Cross concern about Red Cross Emblem shall undoubtedly be mentioned. For that reason PRC in its enactment of $2004^{48}$ approved its official 'Guide on Protection of Red Cross Emblem’ available online at: http://www.pck.org.pl/pliki/wydawnictwa/Ksiazki/Przewodnik_o_ochronie_znaku.pdf; on the grounds of decisions taken in year $2005^{\overline{49}}$ a Commission for Protection of Red Cross Emblem has been founded, whose task is to review if any breaches of the protection take place, to send warning letters in case of such misconducts, to negotiate and in case of goodwill of the other party undertake an attempt to find a compromise In case the latter is impossible, raising alarm on media and if all other steps fail, undertaking judicial proceedings.

\section{Final Remarks}

While analyzing Polish contribution to meet international standards of protection and prevention in the situation of an armed conflict, some general trends shall be noticed. As a member of international community, Poland participated along other western States in the process of development of international humanitarian law since regaining its independence after the I World War. The process was greatly influenced, however, by the USSR. Significant stagnation lasted until late 70 's, as all the members of

48 Uchwała No. 287/2004 ZG PCK.

49 Uchwała No. 445/2005 ZG PCK. 
the block were reluctant in undertaking any international obligations, especially in the military field. Among numerous symptoms of such attitude, let serve the political decision of not including in the Polish Penal Code war crimes as a separate offence ${ }^{50}$. Political breakthrough of the 90 's also meant a revival in IHL in Poland. Even though a lot has been already achieved, the task is still far from being completed, just to mention delayed until 2015 ratification of the Ottawa Treaty of 1997.

\section{Bibliography}

Bothe M., Kurzidem T., Macalister-Smith P. (eds.), National Implementation of International Humanitarian Law, Martinus Nijhoff, Dordrecht 1990.

Bouvier A., Sassoli M., How Does Law Protect in War?, ICRC, Geneve 1999.

Czapliński W., Wyrozumska A., Prawo Międzynarodowe Publiczne, C.H. Beck, Warszawa 2004.

Derlicka K., Vingt ans de DIH en Pologne, Magazine du Mouvement International de la Croix-Rouge et du Croissant-Rouge.

Edukacja Obywatelska w Wojsku, No. 17, Ministerstwo Obrony Narodowej, 2006.

Fleming M., Wojciechowska J., Zbrodnie Wojenne. Przestępstwa przeciwko pokojowi, państwu i obronności, C.H. Beck, Warszawa 1999.

Frankowska M., Prawo Traktatów, Szkoła Główna Handlowa, Warszawa 1997.

Gardocki L., Polskie Prawo Konstytucyjne, Liber, Warszawa 2002.

Gąska M., Obronność w aktach prawnych Rzeczypospolitej Polskiej, Akademia Obrony Narodowej, 2000.

Haug H., Humanity for All, Henry Dunant Institute, Geneva 1993.

ICRC, National implementation of international humanitarian law. Biannual update on national legislation and case law. January-June 2004.

Kalshoven F. (ed.), Implementation of International Humanitarian Law, Nijhoff, Dordrecht 1990.

Masternak-Kubiak M., Umowa Międzynarodowa w Prawie Konstytucyjnym, PWN, Warszawa 1997.

\section{Other sources:}

UN Charter, http://www.un.org/aboutun/charter/.

50 K. Drzewicki, International Humanitarian Law and Domestic Legislation With Special Reference to Polish Law, p. 40-42, za: K. Drzewicki, National Legislation and International Humanitarian Law, in: Implementation of International Humanitarian Law, ed. F. Kalshoven, Nijhoff, Dordrecht 1990, p. 129. 
Polish Constitution (English version), http://www.sejm.gov.pl/prawo/konst/angielski/kon $1 . h t m$.

States Parties to the main humanitarian treaties, http://www.icrc.org/web/eng/siteeng0.nsf/iwpList2/Humanitarian_law:Treaties_and_customary_law?OpenDocument.

Institute of Science Military Information - dissemination and implementation of IHL in Polish Armed Forces, http://www.coniw.wp.mil.pl/modules.php?na$\mathrm{me}=\mathrm{News} \&$ file $=$ article $\&$ sid $=366$.

\section{Streszczenie}

Analizując udział Polski w realizacji międzynarodowych norm ochrony i prewencji w sytuacji konfliktu zbrojnego zauważyć można pewne ogólne trendy. Będąc członkiem społeczności międzynarodowej, Polska brała wraz z innymi państwami zachodnimi udział w procesie rozwoju międzynarodowego prawa humanitarnego od odzyskania niepodległości po pierwszej wojnie światowej. Na proces ten ogromny wpływ wywierał jednak ZSSR. Znacząca stagnacja trwała aż do końca lat siedemdziesiątych, ponieważ wszyscy członkowie bloku niechętnie podejmowali jakiekolwiek zobowiązania międzynarodowe, zwłaszcza w sferze militarnej. Jedną z licznych oznak tego stosunku niech będzie polityczna decyzja o nieumieszczeniu w polskim kodeksie karnym zbrodni wojennych jako odrębnego przestępstwa. Polityczny przełom w latach dziewięćdziesiątych oznaczał także odrodzenie międzynarodowego prawa humanitarnego w Polsce. Wprawdzie wiele już osiagnięto, jednak wiele jeszcze zostało do zrobienia, żeby wspomnieć chociażby ratyfikację Traktatu Ottawskiego z 1997 r., odłożoną do 2015 r. 